\title{
Dissipation of energy of a circular jet submerged in water
}

\section{La dissipation d'énergie d'un jet circulaire submergé dans l'eau}

\author{
N.S. GOVINDA RAO \\ PROFESSOR,
} CIVIS AND HYDRAULIC ENGINEERING SECTION,
BY

\section{K. SEETHARAMAIAH}

ASSISTANT PROFESSOR,

GIVIL AND HYDRAULIC ENGINEERING SECTION,

AND

\author{
N. V. CHANDRASEKHARA SWAMY \\ SENIOR SCIENTIFIC OFFICER, \\ GIVIL AND HXDRAULIC ENGINEERING SECTION, \\ INDIAN INSTITUTE OF SCIENCE, BANGALORE 12 (INDIA)
}

\begin{abstract}
This paper deals with the study of the dissipation of energy of a high velocity jet flowing into a standing mass of water. At the instant when the jet enters the standing pool of water, the jet possesses the maximum energy which gets gradually dissipated along its passage in the surrounding medium. This paper reports some studies undertaken with a view of studying the mechanism by which the energy of the jet gets decreased to a minimum. A hypothesis for the existence of a critical region where the energy of the jet gets reduced to a minimum has been put forward and found to hold experimentally. Studies are also reported regarding the magnitudes of bed velocities under various conditions of flow.
\end{abstract}

\begin{abstract}
Le présent rapport traite d'une étude de la dissipation de l'énergie d'un jet d̀ vitesse élevée pénétrant dans une masse d'eau statique. Au moment où le jet pénètre cette masse d'ean, il possède son énergie maximale, qui se trouve alors progressivement dissipée à nesure que le jet pénètre plus loin dans le nilieu qui l'entoure. Les auteurs font état de quelques études effectuées pour examiner le processus suivant lequel l'énergie du jet diminue jusqu'à sa valenr. minimale; ils formulent l'hypothèse de l'existence d'une région critique, à l'intérieur de laquelle l'énergie du jet est réduite au minimum, hypothèse qu'ils justifient par voie expérimentale. Enfin, ils évoquent des recherches effectuées pour examiner les valeurs des vitesses sur le fond, pour différents régimes d'écoulement.
\end{abstract}

\section{INTRODUCTION}

The problem of the dissipation of energy of a circular jet has been investigated by various research workers using diverse methods. The most important investigations are those of Tollmien [1] who made use of Prandtl's Momentum Transfer Hypothesis, which were confirmed experimentally by Forthmann [2]. Howarth [3]
Divers chercheurs ont étudié le problème de la dissipation de l'énergie d'un jet circulaire au moyen de diverses méthodes. Les plus importantes études réalisées dans ce domaine sont celles de Tollmien [1], qui utilisa la théorie de transfert de quantité de mouvement de Prandtl, et les travaux de Forthmann [2] qui ont confirmé 
studied the same problem using Taylor's Vorticity Transfer Hypothesis, but the experimental accord was not as good as in the case of Momentum Transfer Hypothesis. Similar analyses were also conducted by Goldstein [4] and Tomotika [5]. An empirical study of the problem based on dimensional considerations has been reported by Albertson, Dai, Jensen and Rouse [6].

Underlying all these investigations are certain common features. The fluid considered is viscous and incompressible. The densities of the jet and the diffusion medium are the same. The jet is assumed to expand linearly and the diffusion medium is infinite in extent. The present work departs from the above-mentioned in that it is finite in extent and stress is laid not so much upon the characteristics of the jet as upon the dissipation of energy brought about by the diffusion medium. The experiments have been done in water, the jet and the diffusion medium being of the same density. expérimentalement les résultats de Tollmien. Howarth [3] a étudić le même problème en reprenant l'hypothèse du transfert d'énergie turbulente de Taylor, mais les résultats de sa vérification expérimentale n’ont pas été aussi satisfaisants que ceux obtenus avec l'hypothèse de transfert de quanlité de mouvement. Des analyses du même genre ont été elfectuées par Goldstein [4] et Tomotika [5]. Enfin, Albertson, Dai, Jensen et Rouse [6] ont relaté une étude empirique du problème, basée sur des considérations dimensionnelles.

Toutes ces études reposent sur certaines caractéristiques communes. On considère un fluide visqueux et incompressible; les densités du jet et du milieu dans lequel il se diffuse sont les mêmes : l'expansion du jet est admise comme obéissant à une loi linéaire, et l'étendue du milieu de diffusion est infinie. Par contre, la présente étude admet un milieu de diffusion fini, et porte son attention principale, non tellement sur les caractéristiques du jet, mais plutôt sur la dissipation d'énergie provoquée par le milieu de diffusion. Les essais ont été réalisés avec de l'eau, les densités du jet et du milieu de diffusion étant égales.

\section{EXPERIMENTAL PROCEDURE PROCÉDE EXPERIMENTAL}

The experimental set-up is shown in Fis.s. 1. It consists of a stilling basin with a $V$-notch at one end for purposes of measuring discharges, the other end consisting of the jet which discharges into the stilling basin. Velocity measurements were made across the sections of
L'installation expérimentale esl montrée yar la figure 1, comme conslituée d'un bassin de tranquillisation muni, à l'une de ses extrémités, d'un déversoir triangulaire pour les mesures de débit, et comportant, à l'autre extrémité, l'enlrée du jet dans le bassin de tranquillisation.

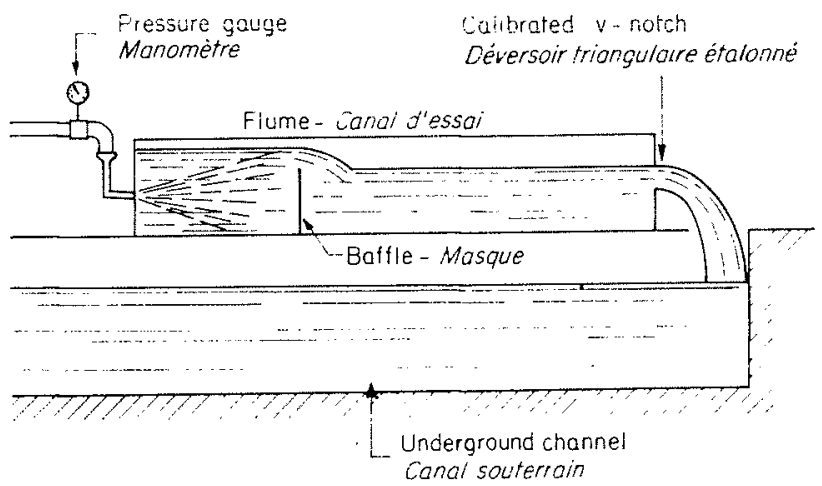

Fig. 1

Experimental set-up for high velocity flow.

Installation d'essai d'un canal à grande vitesse d'écoulement. 


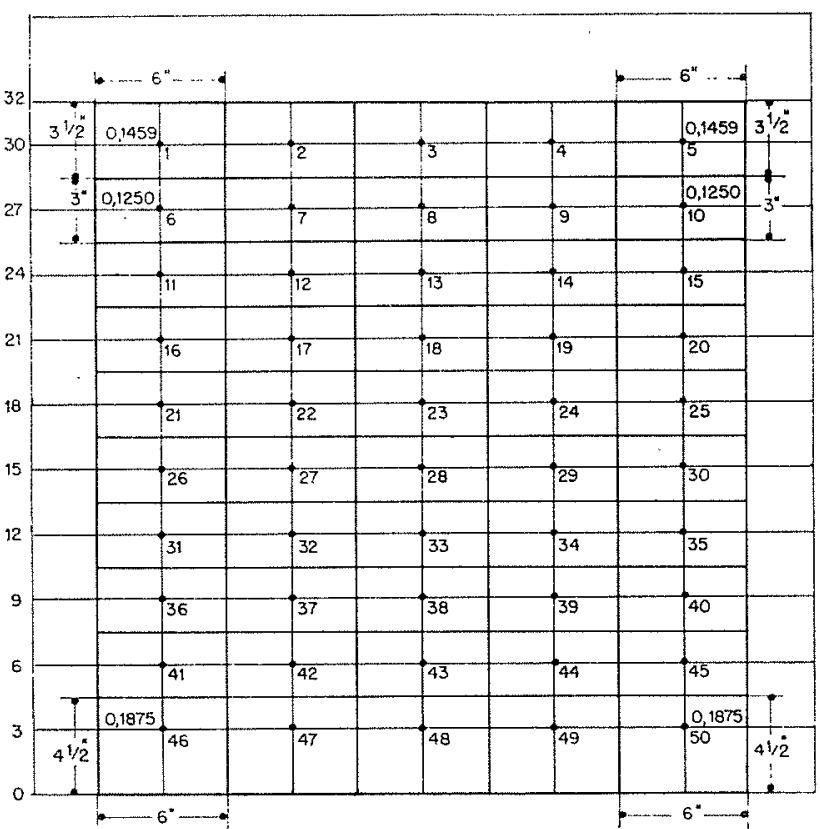

the stilling basin by using a Pitot tube. Measurements were made at jet velocities of 15,30 and $45 \mathrm{ft} / \mathrm{sec}$; the diameter of the jet remaining 1 inch throughout. The length of the stilling basin was varied by using a flexible baffle, the lengths considered being $6 \mathrm{ft}, 9 \mathrm{ft}$, and $12 \mathrm{ft}$. from the efflux section. The axis of the jet was 21 ins. above the floor level and the depths in the stilling basin, for which studies were conducted, were 24,28 and 32 ins. above berlevel.

The kinetic energy of the jet at various crosssections was determined by conducting velocity traverses across each section as shown in Fig. 2. Velocity measurements were made at intervals of $6^{\prime \prime}$ horizontally and $3^{\prime \prime}$ vertically. The areas enclosing the points, where the velocity measurements were made, were rectangular and it was assumed that the velocity at the centre of the area, which, incidentally, is the point of velocity measurement, was the average over that small area.

The total kinetic energy across any cross-section was calculated from :

$$
\mathrm{E}=(1 / 2) \int^{s_{\mathrm{o}}} \mathrm{V}^{3} \delta \mathrm{A}
$$

where $p$ is the density of the fluid, $V$ the average velociry over the area $\delta \mathrm{A}$. Integration was done over the cross-sectional area, $\mathrm{S}$.
FIG. 2

Velocity grid for calculating total energy. Tail water level $32^{\prime \prime}$.

"A" for grids $1,2,3,4,5: 0.1459 \mathrm{sft}$

" $A$ " for grids 6 to $45: 0.1250 \mathrm{sft}$

" $A$ " for grids 46 to $50: 0.1875 \mathrm{sft}$

La grille des vitesses pour le calcul de l'énergie totale. Plan d'eau aval $813 \mathrm{~mm}$.

« $A$ pour carrés $1,2,3,4,5: 135,5 \mathrm{~cm}^{2}$

《A 》 pour carrés 6 à $45: 116 \mathrm{~cm}^{2}$

«A pour carrés 46 à $50: 174 \mathrm{~cm}^{2}$

Des mesures de vitesses ont été effectuées en diverses sections du bassin de tranquillisation au moyen d'un tube de Pitot, pour des vitesses du jet de $4,57,9,14$ et $13,71 \mathrm{~m} / \mathrm{s}$, et pour un diamètre de jet constant de $25,4 \mathrm{~mm}$. Un masque souple amovible permettait de faire varier la longueur du bassin de tranquillisation. Les longueurs utilisées ont été de $1,23,2,75$ et $3,65 \mathrm{~m}$, mesurées à partir de la section d'entrée du jet. L'axe du jet était à $305 \mathrm{~mm}$ au-dessus du fond $\mathrm{du}$ bassin de tranquillisation et les hauteurs d'eau au-dessus du fond étaient, successivement, de 609,711 et $813 \mathrm{~mm}$.

L'énergie cinétique du jet dans diverses sections transversales a été déterminée en explorant le champ de vitesses dans chaque section, comme le montre la figure 2. Les mesures de vitesse ont été effectuées en des points espacés de $152 \mathrm{~mm}$ dans le sens horizontal et de $76 \mathrm{~mm}$ dans le sens vertical. Les surfaces renfermant ces points de mesure étaient rectangulaires, et il a été supposé que la vitesse au point central de chaque petit rectangle (ce point étant, en même temps, le point auquel la vitesse a été mesurée) correspondait à la vitesse moyenne dans le rectangle en question.

L'énergie cinétique dans chaque section transversale a été calculée par l'expression suivante :

$$
\mathrm{E}=(1 / 2) \int^{s} \rho \mathrm{V}^{3} \delta \mathrm{A}
$$

étant la densité du fluide, $V$ la vitesse moyenne dans l'aire $\delta A$. L'intégration s'est faite sur la section $\mathrm{S}$. 


\section{DISCUSSION OF RESULTS EXAMEN DES RÉSULTATS}

At the instant when the jet of water flows into the standing mass of water, the stilling basin is at rest, i.e. the kinetic energy of the jet is maximum and that of the stilling basin is a minimum, which, in this case is zero to start with. As the distance from the efflux section increases, the jet loses its kinetic energy and a part of it is imparted to the stilling basin. The turbulence then created in the stilling basin is not a stationary process, but a process of decay with respect to the distance from the efflux section. The energy of the jet decreases, partly due to viscosity and partly due to turbulent transfer of energy to the stilling basin. There is evidently a section where the energy of the jet transferred to the stilling basin equals that destroyed by turbulent forces. Before this section, the energy transference is more than that destroyed by turbulence and hence the energy of the stilling basin is large. Beyond this section, the energy supplied by the jet falls off in comparison to turbulence forces and the flow becones tranquil.

Accordingly, the mixing region can be divided into two parts, the first characterised by predominant energy dissipation, the second being more or less tranquil with very little energy dissipation. Experiments conducted in this context confirmed the existence of a critical section as shown in Figs. 3 and 4 (vide Tables 1 and 2). These figures indicate the ratio of the total
Au moment où le jet d'eau pénètre dans la masse d'eau au repos, le bassin de tranquillisation est au repos, c'est-à-dire l'énergie cinétique du jet est maximale, et celle du bassin de tranquillisation minimale, autrement dit partant de zéro dans le présent cas. A mesure que la distance de la section d'entrée augmente, le jet perd de plus en plus son énergie cinétique, dont une partie est communiquée au bassin. La turbulence ainsi créée dans le bassin n'est pas un processus stationnaire, mais un phénomène de dégradation évoluant en fonction de la distance do la section d'entrée. L'énergie du jet décrôtt, d'une part à cause de la viscosité, et d'autre part à cause du transfert turbulent d'énergie au hassin de dissipation. Il existe évidemment une cerlaine section, dans laquelle l'énergie du jet transférée au bassin est égale à celle détruite par les forces turbulentes. En amont de cette scotion, l'énergie transférée est plus grande que celle détruite par la turbulence, et l'énergie du bassin de tranquillisation est élevée. Par contre, au-dela de cette section, l'énergie fournie par le jet diminue par rapport aux forces de turbulence, et l'écoulement devient tranquille.

Il s'ensuit que la zone de mélange peut être considérée comme étant divisée en deux parties, dont la première est caractérisée par la prédominance du phénomène de dissipation d'énergie, la seconde étant plus ou moins tranquille et ne présentant qu'une très faible dissipation d'énergie. Des essais réalisés dans ce contexte ont vérifié l'existence d'une section critique (voir fig. 3

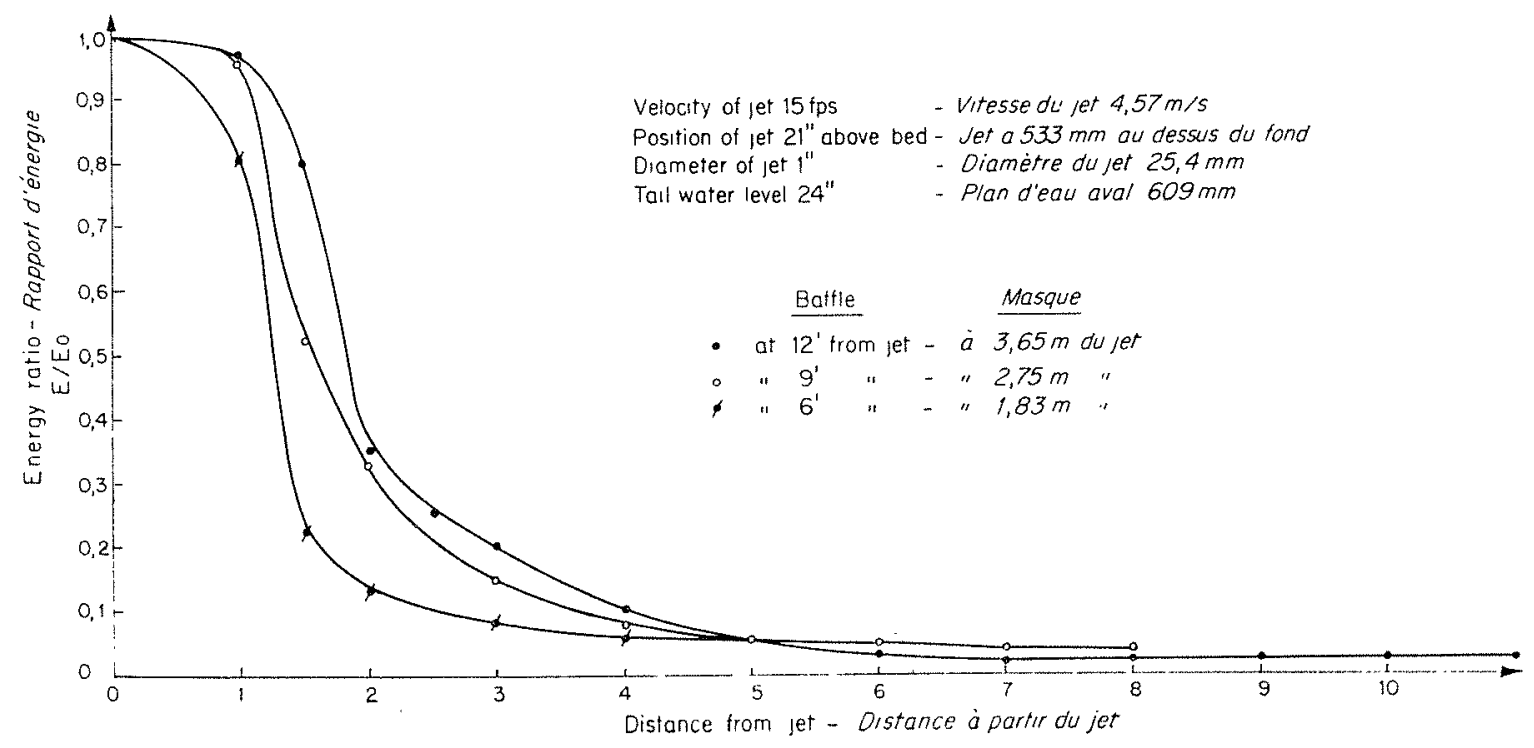

- Fig. 3 


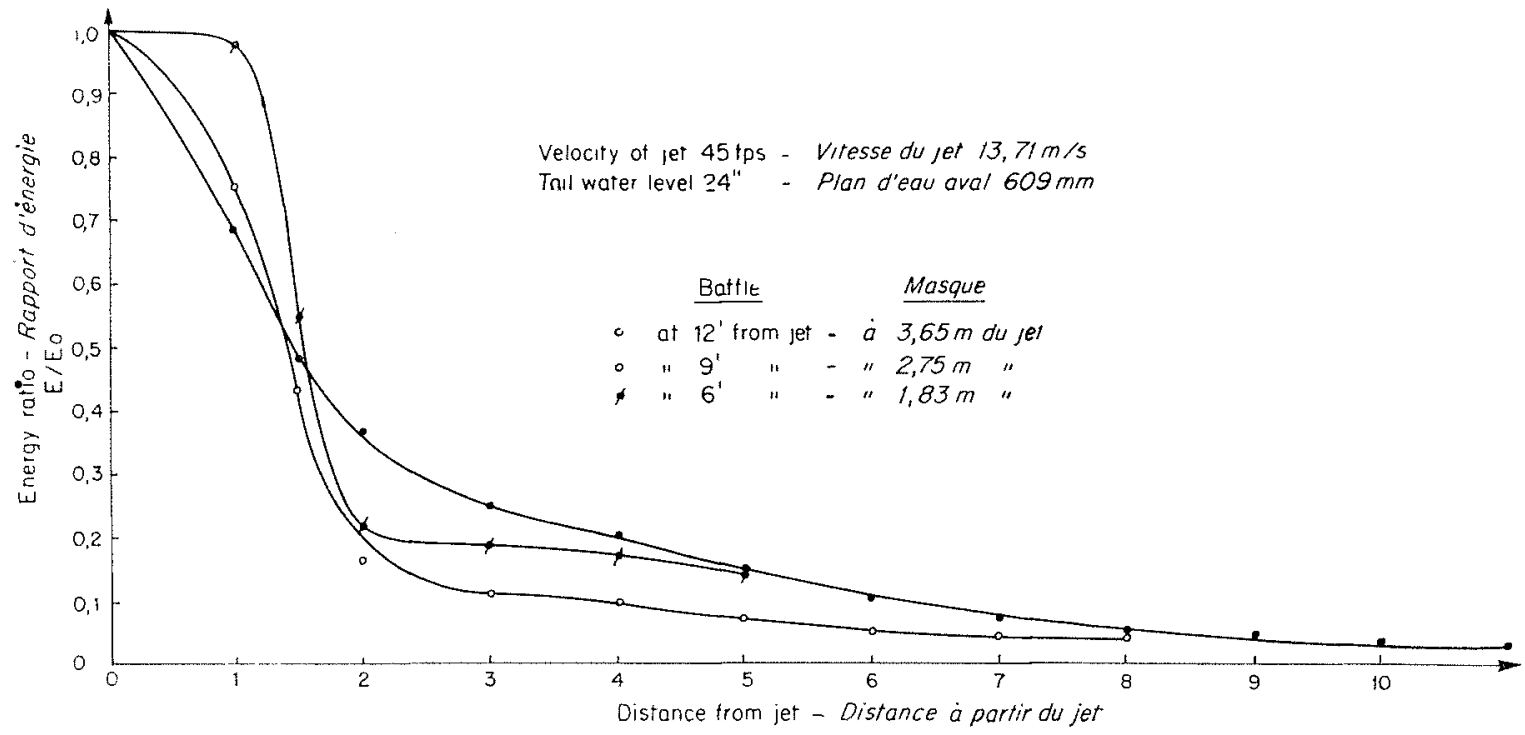

FIG. 4

TABLE I. - Velocity of JET : $15 \mathrm{fps}$.

Tall water LEVEL : 32 inches

TABLEAU I. - Vitesse du jet : $4,57 \mathrm{~m} / \mathrm{s}$ Plan d'eau aval : $813 \mathrm{~mm}$

\begin{tabular}{|c|c|c|c|c|c|}
\hline \multirow[b]{2}{*}{$\begin{array}{l}\text { Sl } \\
\text { No. }\end{array}$} & \multicolumn{5}{|c|}{$\mathrm{E} / \mathrm{E}_{0}$} \\
\hline & 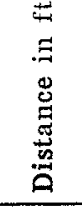 & 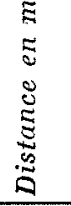 & $\begin{array}{c}\text { Baffle } \\
\text { at } 12 \mathrm{ft} \\
\text { Masque } \\
\dot{\alpha} 3,65 \mathrm{~m}\end{array}$ & $\begin{array}{c}\text { Baffle } \\
\text { at } 9 \mathrm{ft} \\
\text { Masque } \\
\text { a } 2,75 \mathrm{~m}\end{array}$ & $\begin{array}{c}\text { Baffle } \\
\text { at } 6 \mathrm{ft} \\
\text { Masque } \\
\dot{a} 1,83 \mathrm{~m}\end{array}$ \\
\hline 1 & 1 & 030 & (1 077 & & \\
\hline 2 & 1.5 & 0,45 & 0.4892 & & \\
\hline 3 & 2 & 0,61 & 0.3305 & & \\
\hline 4 & 2.5 & 0,76 & 0,2851 & & \\
\hline 5 & 3 & 0,91 & 0.2294 & & \\
\hline 6 & 3,5 & 1,06 & 0,2151 & & \\
\hline 7 & 4 & 1,22 & 0.1756 & & \\
\hline 8 & 5 & 1,52 & 0.1533 & & \\
\hline 9 & 7 & 2,13 & 0.0894 & & \\
\hline 10 & 9 & 2,75 & 0.0600 & & \\
\hline 11 & 11 & 3,35 & 0.0510 & & \\
\hline 12 & 1 & 0,30 & & 0.7473 & \\
\hline 13 & 1.5 & 0,45 & & 0.6685 & \\
\hline 14 & 2 & 0,61 & & 0.3178 & \\
\hline 15 & 2.5 & 0,76 & & 0.2321 & \\
\hline 16 & 3 & 0,91 & & 0.2091 & \\
\hline 17 & 4 & 1,22 & & 0.2071 & \\
\hline 18 & 6 & 1,83 & & 0.1264 & \\
\hline 19 & 8 & 2,44 & & 0.0526 & \\
\hline 20 & 1 & 0,30 & & & 0.9546 \\
\hline 21 & 1.5 & 0,45 & & & 0,6918 \\
\hline 22 & 2 & 0,61 & & & 0.5601 \\
\hline 23 & 3 & 0,91 & & & 0.2771 \\
\hline 24 & 4 & 1,22 & & & 0.2665 \\
\hline 25 & 5 & 1,52 & & & 0.1762 \\
\hline
\end{tabular}

TABLE II. - Velocity OF JET : $45 \mathrm{fps}$. TAIL WATER LEVEL : 24 inches

TABLEAU II. - Vitesse du jet : $13,71 \mathrm{~m} / \mathrm{s}$ Plan d'eau aval : $731 \mathrm{~mm}$

\begin{tabular}{|c|c|c|c|c|c|}
\hline \multirow[b]{2}{*}{$\begin{array}{l}\text { Sl } \\
\text { No. }\end{array}$} & \multicolumn{5}{|c|}{$\mathrm{E} / \mathbf{E}_{0}$} \\
\hline & 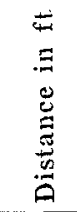 & 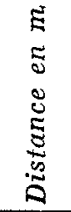 & $\begin{array}{c}\text { Baffle } \\
\text { at } 12 \mathrm{ft} \\
\text { Masque } \\
\text { a } 3,65 \mathrm{~m}\end{array}$ & $\begin{array}{c}\text { Baffle } \\
\text { at } 9 \mathrm{ft} \\
\text { Masque } \\
\dot{a} 2,75 \mathrm{~m}\end{array}$ & $\begin{array}{c}\text { Baffle } \\
\text { at } 6 \mathrm{ft} \\
\text { Masque } \\
\dot{a} 1,83 \mathrm{~m}\end{array}$ \\
\hline & & & & & \\
\hline $\begin{array}{l}1 \\
2\end{array}$ & 1.5 & $\begin{array}{l}0,30 \\
0.45\end{array}$ & 0.4876 & & \\
\hline 3 & 2 & 0,61 & 0.3656 & & \\
\hline 4 & 2,5 & 0,76 & 0.2934 & & \\
\hline 5 & 3 & 0,91 & 0.2444 & & \\
\hline 6 & 3.5 & 1,06 & 0.2258 & & \\
\hline 7 & 4 & 1,22 & 0.2062 & & \\
\hline 8 & 5 & 1,52 & 0.1741 & & \\
\hline 9 & 7 & 2,13 & 0.0740 & & \\
\hline 10 & 9 & 2,75 & 0.0469 & & \\
\hline 11 & 11 & 3,35 & 0.0225 & & \\
\hline 12 & 1 & 0,30 & & 0.7565 & \\
\hline 13 & 1.5 & 0,45 & & 0.4397 & \\
\hline 14 & 2 & 0,61 & & 0.1600 & \\
\hline 15 & 2.5 & 0,76 & & 0.1552 & \\
\hline 16 & 3 & 0,91 & & 0.1179 & \\
\hline 17 & 4 & 1,22 & & 0.1063 & \\
\hline 18 & 6 & 1,83 & & 0.0564 & \\
\hline 19 & 8 & 2,44 & & 0.0460 & \\
\hline 20 & 1 & 0,30 & & & 0.9942 \\
\hline 21 & 1,5 & 0,45 & & & 0.5495 \\
\hline 22 & 2.0 & 0,61 & & & 0.2161 \\
\hline 23 & 3 & 0,91 & & & 0.1892 \\
\hline 24 & 4 & 1,22 & & & 0.1665 \\
\hline 25 & 5 & 1,52 & & & 0.1227 \\
\hline
\end{tabular}


kinetic energy at any section to the kinetic energy of the jet plotted against the distance from the efflux section. These figures give a value of $5 \mathrm{ft}$. for the critical section at which the flow characteristics change predominantly. The existence of this critical section at a constant distance from the efflux section for the range of velocities, submergences and stilling basin lengths indicates that it is independent of these variables in the range considered.

The existence of the critical section is of considerable importance in the design of stilling basins. The experimental values obtained for the energy of the flow beyond the critical section indicate that the energy of flow is probably the minimum necessary to keep up the flow. Hence the design of protective works beyond the critical section should prove to be of less interest than that before it.

The study of the dissipation of energy in the first region leads to some interesting conclusions. The percentage of energy dissipated before the critical section is considerably large compared to the residual energy after it. Since a large percentage of kinetic energy is dissipated within

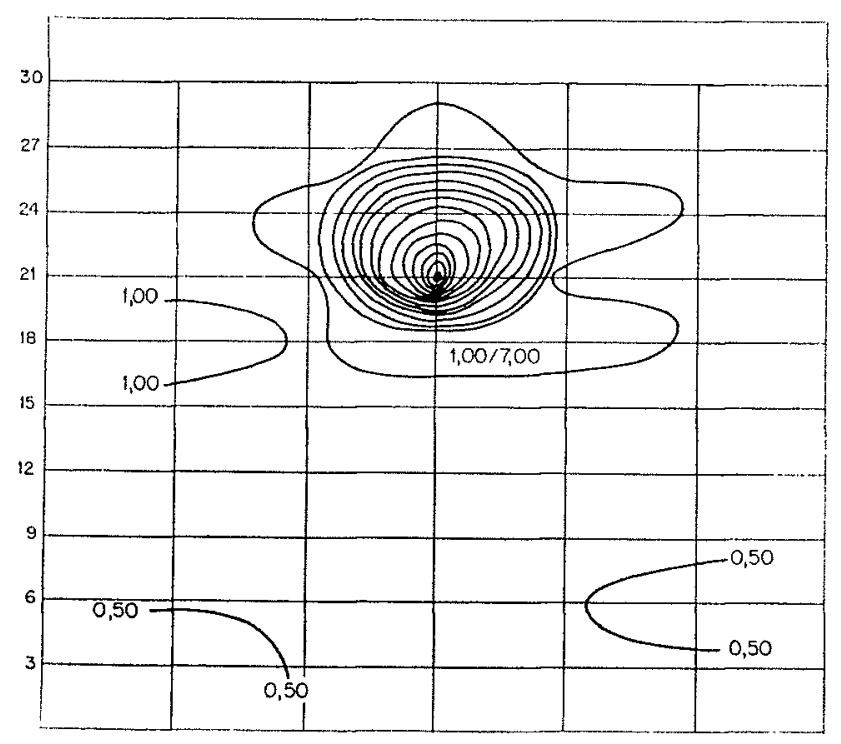

FIG. 5

Vélocity distribution -- Répartition des vitesses ( $\mathrm{ft} / \mathrm{s}$ ). Velocity of jet: $45 \mathrm{fps}$, Diameter of jet: $1^{\prime \prime}$, Position of jet: $21^{\prime \prime}$ above bed, Tail water level: $32^{\prime \prime}$, Position of baffe: $12^{\prime}$ from jet. Section at 1 foot

Vitesse du jet : $13,71 \mathrm{~m} / \mathrm{s}$, Diamètre du jet : $25,4 \mathrm{~mm}$, Position du jet : $633 \mathrm{~mm}$ au-dessus du fond, Plan d'eau aval : $813 \mathrm{~mm}$, Position du masque : à $3,65 \mathrm{~m}$ du jet. Section à $305 \mathrm{~mm}$ de l'entrée du jet et 4 , ainsi que les tableaux 1 et 2). Ces figures montrent le rapport de l'énergie cinétique totale en n'importe quelle section, à l'énergie cinétique du jet, en fonction de la distance de la section d'entrée du jet. On voit que cette section critique, dans laquelle les caractéristiques de l'écoulement se modifient nettement, se situe à $1,52 \mathrm{~m}$ de la section d'entrée du jet. L'existence de cette section critique à une distance constante de la section d'entrée, pour les gammes de vitesses, submersions et longueurs de bassin de tranquillisation considérées, indique qu'elle est indépendante de ces variables dans la gamme étudiée.

L'existence de la section critique est d'une très grande importance pour l'étude des bassins de tranquillisation. Les valeurs expérimentales obtenues pour l'énergie de l'écoulement au-delà de la section critique indiquent que cette énergie est probablement le minimum d'énergie nécessaire pour maintenir l'écoulement. Il semblerait donc qu'il y ait moins d'intérêt à prévoir des ouvrages de protection en aval de cette section critique qu'en amont.

L'étude de la dissipation d'énergie dans la première zone donne lieu à d'intéressantes conclusions. Le pourcentage d'énergie dissipé en amont de la section critique est très élevé par rapport à l'énergie résiduelle en aval de cette même section. Etant donné qu'un fort pourcentage de l'énergie cinétique est dissipé à l'intérieur d'une zone très étroite, la pente de la ligne de charge est assez raide. L'aspect de la dissipation de

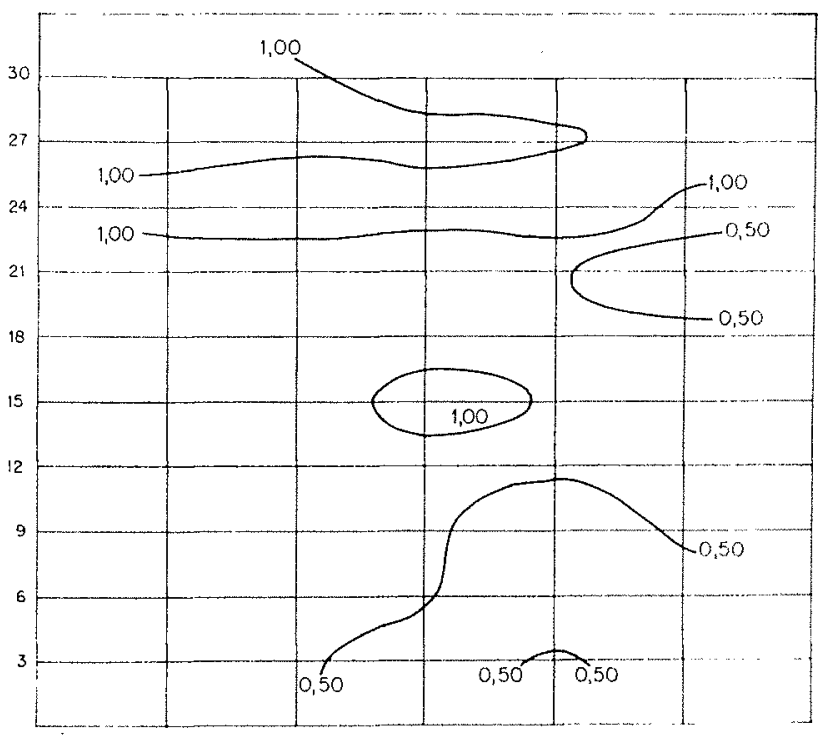

FIG. 6

Vélocity distribution - Répartition des vitesses (ft/s). Section at 9 feet

Section à $2,75 \mathrm{~m}$ de l'entrée du jet 
a very narrow region, the energy gradient is fairly steep. The variation in the pattern of energy dissipation with the conditions of flow is very marked and because of the large variation it is difficult to evolve a mean pattern which can represent the energy dissipation on an average.

But it is evident that in most of the cases, the dissipation of energy in the region very near the mouth of the jet is very rapid and gradually decreases as the longiludinal distance increases. In other words, the magnitude of turbulent shear developed near the mouth of the jet is of a high order and decreases with the longitudinal distance.

Measurements of velocity were conducted at various cross-sections and velocity contours have been drawn, which help in the analysis of energy dissipation. The variation in the pattern of the contours with distance from the efflux scction is an indication of the degree of energy dissipation. Some typical and representative contours are given in Figs. 5 and 6.

At the efflux section, the region of flow is confined to the diameter of the jet and the surrounding medium has zero energy. But as the distance from the efflux section increases, the region in which the velocity contours are concentrated, indicating low diffusion and high energy gradient, increases in area. This region of concentrated contours slowly expands until a stage is reached when it extends over the entire cross-section and consequently loses its individuality. The figures which trace the history of the jet reveal that, this "core" of flow where the velocity contours are concentrated expands and the axial velocity decreases. The lateral gradient of velocity decreases so that the entire cross-section becomes uniform. This is the history of the jet which is repeated in every case when the flow conditions are changed.

It is evident, from the difference between the expansion of the jet in the present case and that in the previous cases (refs. 1-6) that the position of the jet was symmetrical about the surrunding medium in the latter and also that the diffusion medium was considered to be free of boundary effects. In the present case, the second condition, that the boundary effects are not felt on the jet, is partially true only of the walls and the floor of the flume. The free surface conforming to hydrostatic laws does have influence on the jet. Its effect is evident from Figs. 5 and 6 . The velocity contours diffuse and get obliterated before they can reach the sides of the flume or its floor. Owing to the free surface, the pattern of velocity contours is not symmetrical about the horizontal plane through the axis of the jet. l'énergie varie très nettement en fonction du régimé d'écoulement, de sorte qu'il est difficile de définir un aspect de dissipation moyen pouvant être considéré comme « aspect-type »de dissipation.

Cependant, il est évident que, dans la plupart des cas, la dissipation d'énergie dans la zone au voisinage immédiat de l'entrée du jet est très rapide, et qu'elle décroît progressivement à mesure que la distance longitudinale augmente. Autrement dit, les valeurs des forces de cisaillement turbulent près de l'entrée du jet sont d'un ordre très élevé et décroissent ensuite en fonction de la distance longitudinale de la section d'entrée.

Des mesures de vitesse ont été effectuées dans diverses sections transversales, et des courbes de répartition des vitesses ont été tracées, facilitant l'analyse de la dissipation d'énergie. Les variations de l'allure de ces courbes à mesure que la distance de la section d'entrée du jet augmente, met en évidence l'intensité de la dissipation d'énergie. Quelques courbes typiques de ce genre sont montrées sur les figures 5 et 6 .

La zone d'écoulement à la section d'entrée est entièrement comprise dans le diamètre du jet, et l'énergie du milieu environnant est zéro. Mais, à mesure que la distance de la section d'entrée augmente, la zone à l'intérieur de laquelle sont concentrées les courbes d'égale vitesse (c'està-dire témoignant d'une zone de faible diffusion et de ligne de charge à pente accusée) s'étend progressivement, jusqu'à ce qu'elle occupe la totalité de la section, et qu'elle ne soit plus une zone distincte. Les valeurs exprimant l'évolution du jet montrent que ce « noyau »d'écoulement, dans lequel les courbes d'égale vitesse sont concentrées, se dilate, et que la vitesse axiale diminue simultanćment. Le gradient de vitesse latéral décroît, de sorte que la section entière devient uniforme. Cette évolution du jet se retrouve à chaque changement du régime d'écoulement.

La différence entre l'expansion du jet dans la présente étude, et celle des études antérieures [voir références 1-6], montre que, dans ces dernières, la position du jet était symétrique par rapport au milieu environnant et que le milieu de diffusion était supposé non soumis à l'influence de conditions limites. Par contre, dans la présente étude, la deuxième de ces conditions (c'est-à-dire l'hypothèse d'un jet non influencé par des conditions aux limites), n'est qu'en partie valable pour les parois et le fond du canal d'essai. La surface libre obéissant aux lois de l'hydrostatique influe en effet sur le jet, comme on peut le voir sur les figures 5 et 6 . Les courbes d'égale vitesse deviennent diffuses et tendent a disparaître avant d'atteindre les parois ou le fond du canal. Du fait de la surface libre, la répartition des courbes de vitesse n'est pas sy- 
The velocity contours shown in Figs. 5 and 6 closely resemble those developed when a stone is dropped into a still pond. The successive graphs represent the various stages in the propagation of the wave. The analogy holds in this respect that the "velocity waves" dissipate laterally till they reach the bottom and the sides where they are damped by viscous forces at the boundary. But the analogy cannot be extended further.

The boundary of the jet, which is circular at the efflux section, gels distorted as it enters the stilling basin. Since, by condition of continuity, the momentum of the jet is constant, and since the velocity of the jet decreases longitudinally, the area of the jet increases and the boundary of the jet expands. At the place where the boundary of the jet reaches the free surface, ripples are formed and the energy dissipation takes place at the surface. But, if the boundary of the jet touches the bed or the sides of the stilling basin there is a possibility of high velocities occurring at the bed. In the present case, it was found that the boundary of the jet was completely distorted out of shape before it could touch the bed or the sides of the stilling basin and hence the velocities at the bed never exceed about $1 \mathrm{ft} / \mathrm{sec}$, as can be observed from Figs. 5 and 6.

Very near the efflux section, the velocity at the bed of the stilling basin is of a low order, being zero in many places. But, as the distance from the efflux section increases, the velocity at the bed increases to some extent and then métrique par rapport au plan horizontal passant par l'axe du jet.

Les courbes de vitesse montrées sur les figures 5 et 6 sont très analogues à celles provoquées par la chute d'une pierre dans un plan d'eau au repos. Les courbes, successivement, représentenl les diverses étapes de la propagation de l'onde. L'analogie est valable dans la mesure où les « ondes de vitesse $\gg$ se dissipent dans le sens latéral jusqu'à ce qu'elles atteignent le fond et les parois, où elles se trouvent amorties par les forces visqueuses aux limites. On ne peut, toutefois, généraliser cette analogie davantage.

La limite du jet, d'abord de forme circulaire à la section d'entrée, se déforme à mesure que le jet pénètre plus loin dans le bassin. Etant donné que, d'après la loi de continuité, la quantité de mouvement du jet est constante, et puisque la vitesse du jet diminue dans le sens longitudinal, la section et les limites de jet augmentent. Des rides se forment à l'endroit où la limite. du jet atteint la surface libre, et la dissipation de l'énergie se fait en surface. Par contre, lorsque la limite du jet atteint le fond ou les parois du bassin, il peut se produire des grandes vitesses au fond. Nous avons pu voir, dans le présent cas, que la limite du jet était complètement diformée avant qu'il ne lui fût possible d'atteindre le fond ou les parois du bassin; les vitesses au fond du bassin n'ont donc jamais dépassé l'ordre de $0,30 \mathrm{~m} / \mathrm{s}$ (voir fig. 5 et 6 ).

$\mathrm{Au}$ voisinage immédiat de la section d'entrée $\mathrm{du}$ jet, la vitesse au fond du bassin est d'un ordre très faible, étant même nulle à plusieurs endroits. Cependant, à mesure que la distance de la section d'entrée augmente, la vilesse au fond

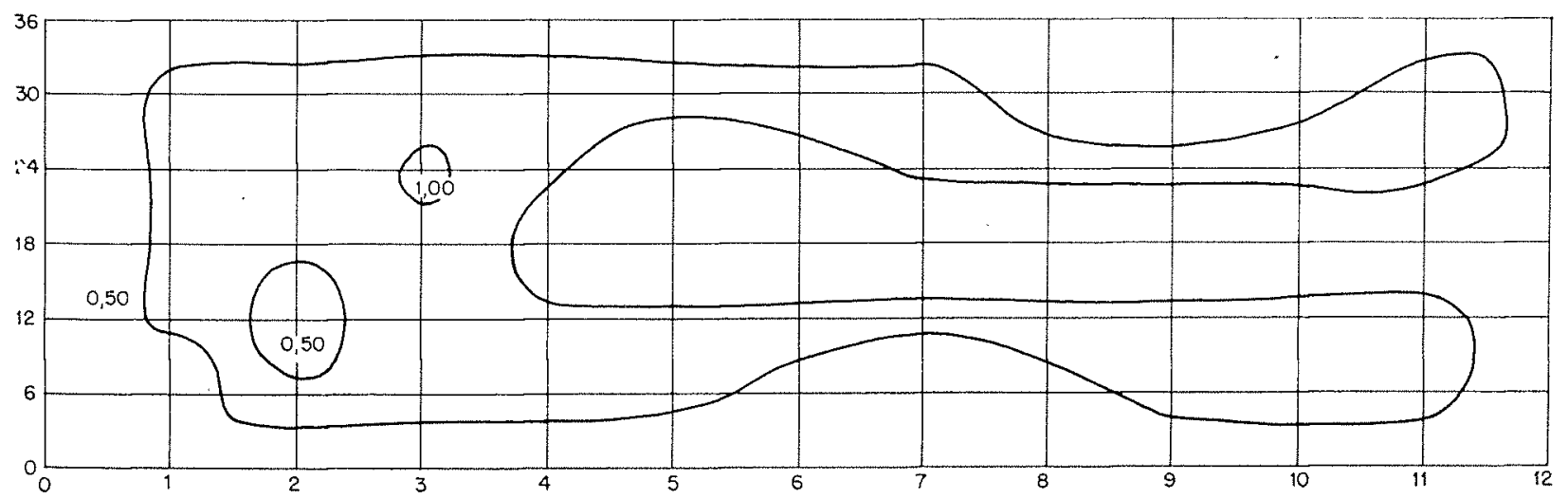

FIG. 7

Bed velocity distribution - Répartition des vitesses sur le fond (ft/s).

3" above bed level, Velocity of jet: $45 \mathrm{fps}$, Tail water level: $32^{\prime \prime}$, Baffle at 12'.
$76 \mathrm{~mm}$ au-dessus du fond, Vitesse du jet : $13,71 \mathrm{~m} / \mathrm{s}$, Plan d'eau aval : $813 \mathrm{~mm}$, Masque a $3,65 \mathrm{~m}$ du jet. 


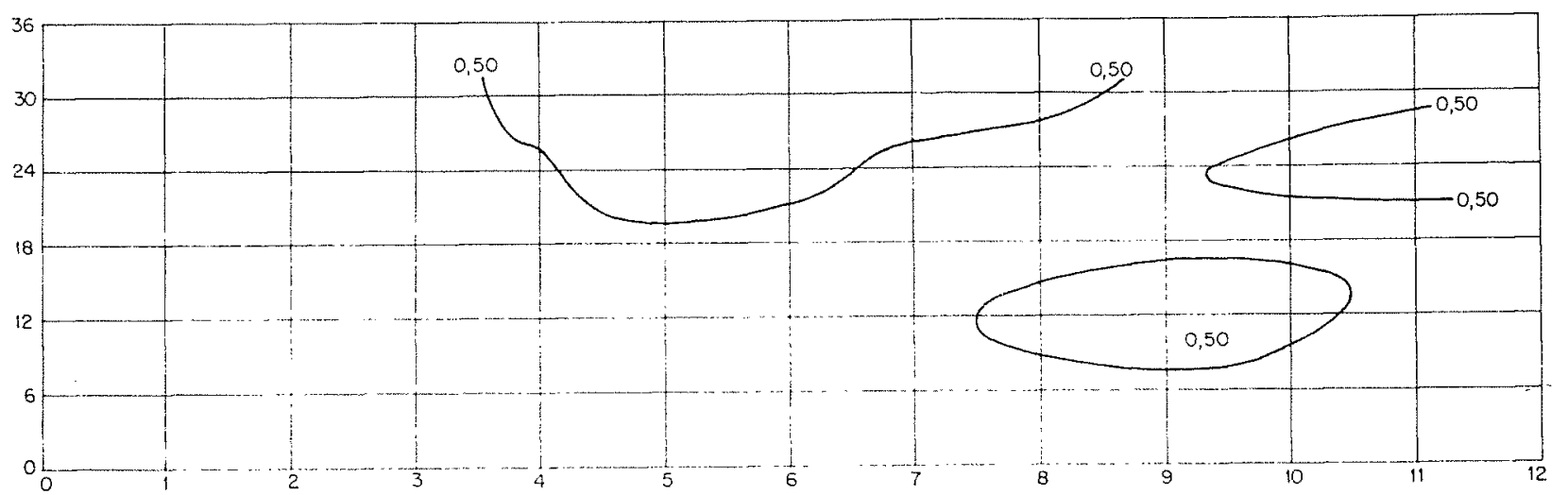

FIG. 8

Bed velocity distribution - Répartition des vitesses sur le fond ( $\mathrm{ft} / \mathrm{s}$ )

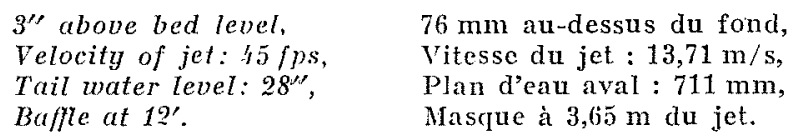

$76 \mathrm{~mm}$ au-dessus du fond, Vitesse du jet : $13,71 \mathrm{~m} / \mathrm{s}$, Plan d'eau aval : $711 \mathrm{~mm}$, Masque à $3,65 \mathrm{~m}$ du jet.

again drops down after the critical section. This effect is partly due to the height of the jet axis above the bed of the flume.

In order to study the effect of the tail water level on the bed velocities, velocity contours at $3^{\prime \prime}$ above the bed were drawn (Figs. 7 and 8). The graphs reveal that with increase in tail water level, the bed velocities also increase. This might be due to the fact that the jet has a tendency to bend which increases the bed velocities. Hence, for every dissipation without bed scour, it appears that the less the submergence of the jet, the less is the bed scour. The minimum submergence of the jet is, of course, that which just manages to submerge the jet. Beyond this, the jet becomes free and the problem no longer remains the same. augimente également dans une certaine mesure, mais diminue de nouveau au-delà de la section critique. Ce phénomène s'explique, en partie, par la hauteur de l'axe du jet au-dessus du fond du canal.

Afin d'étudier l'influence du niveau aval sur les vitesses au fond, nous avons tracé des courbes d'égale vitesse à $76 \mathrm{~mm}$ au-dessus du fond (fig. 7 et 8). Ces graphiques montrent que l'augmentation du niveau aval fait également augmenter les vitesses au fond, ce qui pourrait s'expliquer par le fait que le jet tend à s'incurver, augmentant ainsi les vitesses au fond. De là, il apparaît que, moins le jet est submergé, moins il proroquera d'affouillement du fond. La submersion minimale est, bien entendu, celle à laquelle le jet est tout juste submergé. Au-delà de cette limite, le jet est libre, et le problème n'est plus le même.

\section{CONCLUSIONS}

The existence of a critical section which divides the region of intense turbulence and energy dissipation from the region of tranquil flow has been experimentally established and the characteristics of the flow in the former region has been studied in detail. The problem as such cannot be applied directly to practice, but will require modifications. But the undisputable existence of the critical section of flow can lead to simplifications in design.

The flow characteristics as studied from the velocity contours have revealed the mechanism
Nous avons pu établir, par voie expérimentale, l'existence d'une section critique séparant la zone de turbulence et de dissipation d'énergie intensives, de la zone d'écoulement tranquille, et nous avons étudié en détail les caractéristiques de l'écoulement dans la première de ces zones. Ce problème ne peut s'appliquer directement dans des conditions pratiques sous la forme présentée; pour ce faire, il serait nécessaire de hui apporter certaines modifications. Cependant, grâce a l'existence incontestable de la section critique d'écoulement, il sera possible de simplifier l'étude des dispositifs de dissipation d'énergie. 
by which the regions of concentrated flow diffuse into the surrounding medium and lose their individuality.

Studies regarding bed velocities indicate that bed velocities of a considerable magnitude occur only in certain individual spots, but if the submergence of the jet is low, the bed velocities do not attain any appreciable magnitude.
Les caractéristiques d'écoulement étudiées à partir des courbes d'égale vitesse ont mis en óvidence le processus suivant lequel les zones d'écoulement concentré diffusent dans le milieu qui les entoure et perdent leur caractère indiriduel.

Il ressort des études des vitesses au fond que celles-ci n'atteignent des valeurs très élevées qu'à certains endroits très particuliers; si, loulefois, le jet n'est que faiblement submergé, ces vitesses ne peuvent atteindre des valeurs appréciables.
1. Tolumien (W.). - Berechnung der Turbulenten Ausbreitungsvorgange, A.Z.M.M., Bd. 4, 468, 1926; also translated as N.A.C.A., TM 1085, 1945.

2. Fonthman (E.). - Ueber turbulente Strahlausbreitung. Ing. Arch., Bd. 5, 42, 1934; also translated as N.A.C.A., TM 789, 1936 .

3. Hownpth (L.). - Concerning the velocity and temperature distribution in plane and axially symmetrical jets. Proc. Camb. Phil. Soc., vol. 34, 185, 1935.
4. Goldstein (S.). - On the velocity and temperature distributions in the turbulent wake. Proc. Camb. Phil. Soc., vol. $34,65,1938$.

5. Tomotika (S.). - Application of the modified vorticity transport theory to the turbulent spreading of a jet of air. Proc. Roy. Soc., vol. 165 A, 65, 1938.

6. Albertson (M. L.) and others, - Diffusion of submerged jets. Trans. A.S.C.E., vol. 115, 639, 1950.

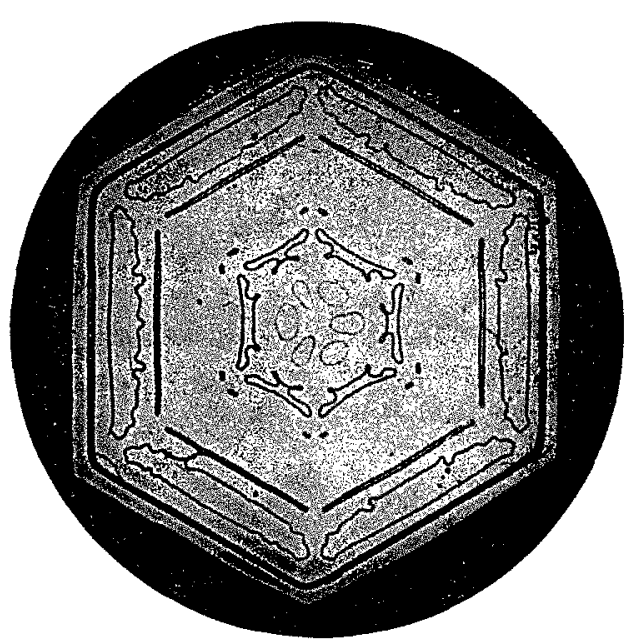

